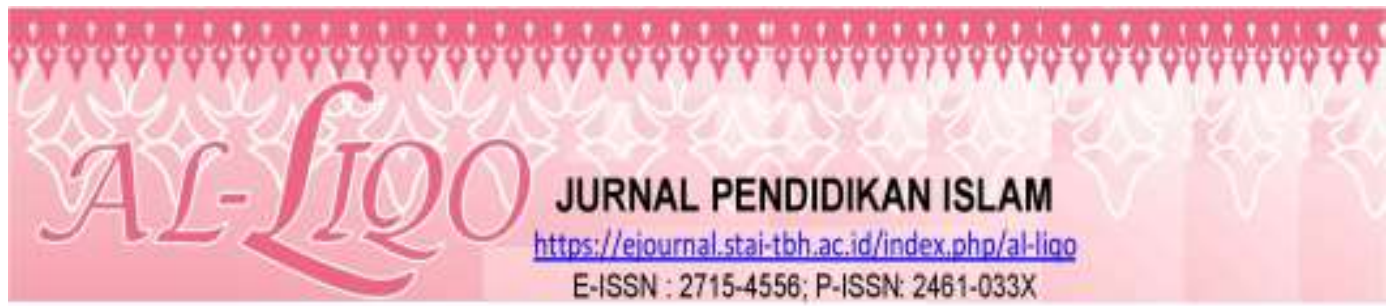

\title{
PEMIKIRAN AMIRULLOH SARBINI DAN AHMAD KHUSAERI TENTANG PENDIDIKAN AKHLAK REMAJA
}

\author{
Dina Liana ${ }^{1)}$ Mardiah $^{2)}$ \\ ${ }^{1}$ Dosen Tetap Program Studi Pendidikan Agama Islam STAI Auliaurrasyidin Tembilahan \\ Kabupaten Indragiri Hilir Propinsi Riau. Email : dina.liana@stai-tbh.ac.id \\ ${ }^{2}$ Dosen Tetap Program Studi Pendidikan Agama Islam STAI Auliaurrasyidin Tembilahan \\ Kabupaten Indragiri Hilir Propinsi Riau. Email : mardiah@stai-tbh.ac.id
}

\begin{abstract}
Abstrak
Pendidikan pada remaja sebagai generasi penerus adalah keharusan bagi orangtua, orangtualah yang memegang peranan sangat dominan dalam pembentukan sikap dan kepribadian anak-anaknya. Pendidikan yang diberikan kedua orangtua di awal pertumbuhan anak merupakan titik mula yang sangat menentukan kesuksesan dan keberhasilannya dalam mengemban amanat sebagai khalifah Allah SWT di bumi yang bersumberkan kepada Al-Qur'an dan Al-Hadits. Keberhasilan proses pendidikan dalam mengantarkan anak mencapai tujuan yang diharapkan, tidak terlepas dari peranan metode yang digunakan, dalam proses pendidikan metode mempunyai kedudukan sangat penting guna mencapai tujuan pendidikan. Oleh karena itu, diperlukan kehati-hatian dalam menentukan metode. Sebab jika salah mengambil suatu metode, tujuan pendidikan tidak akan tercapai bahkan akan membawa mudharat terhadap anak didik. Rumusan masalah yaitu; bagaimana biografi Amirulloh Syarbini dan Akhmad Khusaeri, bagaimana pemikiran mereka tentang pendidikan akhlak remaja, serta metode apa yang cocok dalam Mendidik Akhlak Remaja.
\end{abstract}

Kata Kunci : Pemikiran Amirulloh Sarbini Dkk, Akhlak Remaja

\section{PENDAHULUAN}

Pendidikan akhlak bagi remaja adalah suatu proses bimbingan untuk membina dan mangarahkan perangai dan tingkah laku remaja sesuai ajaran Islam demi terwujudnya akhlak mulia. Selanjutnya pendidikan akhlak sifatnya integratik bukan monolitik, artinya pendidikan tidak berdiri sendiri, bukan mata pelajaran atau jenis studi, tetapi terintegrasi dalam setiap jenis sistem, dan model pendidikan manapun, baik pendidikan formal, informal maupun non formal. Pendidikan akhlak diberikan kepada anak remaja untuk membentuk remaja berakhlak mulia, sopan dalam berbicara, bertindak bijaksana, beradab mulia dalam tingkah laku, memegang teguh perangai yang baik, menjauhkan diri dari 
perangai yang jahat, berkemauan keras untuk belajar, dan taat kepada Allah SWT yang bersumberkan kepada Al-Qur'an dan Al-Hadits. ${ }^{1}$ Pendidikan terhadap anak/remaja sebagai generasi penerus adalah keharusan bagi orangtua, orangtualah yang memegang peranan sangat dominan dalam pembentukan sikap dan kepribadian anak-anaknya. Pendidikan yang diberikan kedua orangtua di awal pertumbuhan anak merupakan titik mula yang sangat menentukan kesuksesan dan keberhasilannya dalam mengemban amanat sebagai khalifah Allah SWT di bumi. ${ }^{2}$

Pendidikan Akhlak dalam Islam telah dimulai sejak anak dilahirkan, bahkan sejak dalam kandungan, perlu disadari bahwa pendidikan akhlak terjadi melalui semua segi pengalaman hidup, baik melalui penglihatan, pendengaran dan pengalaman atau perlakuan yang diterima atau melalui pendidikan, dalam arti yang luas pembentukan akhlak dilakukan setahap demi setahap sesuai dengan irama pertumbuhan dan perkembangan serta proses yang dialami. ${ }^{3}$

Hal itu disebabkan karena tujuan utama pendidikan adalah untuk menjamin masa depan anak di akhirat. Masa kanak-kanak sangat penting karena pada asalnya jiwa anak adalah murni dan terbuka terhadap pengaruh. Karakternya tertulis diatasnya sebagaimana pena di atas kertas putih. Dan bukan saja masa depan anak ditentukan oleh pendidikannya, tetapi juga oleh para pendidiknya". ${ }^{4}$

Maka wajar jika para pendidik ditekankan untuk memperhatikan pendidikan anak, terutama mengenai pendidikan akhlaknya. Sedangkan Islam mempunyai sistem pendidikan dan metode pembinaan. Ketika para pendidik mempergunakan sistem dan metode ini, maka kemantapan, kesentosaan dan kebahagian akan menggantikan kekacauan, kecemasan dan kesengsaraan, dan akan tampak jelas pula bagi kedua mata anda bahwa Islam adalah agama kehidupan, agama kemanusiaan, agama kesadaran, pendidikan dan pembinaan. ${ }^{5}$ Islam telah memberikan gambaran bagaimana membentuk seseorang agar

\footnotetext{
${ }^{1}$ Amirulloh Syarbini dan Akhmad Khusaeri, Kiat-Kiat Islami Mendidik Akhlak Remaja, (Jakarta, Gramedia, 2012), hlm. 38

${ }^{2}$ Musa Turoichan, Kado Perkawinan, Kiat Menciptakan Surga Dalam Rumah Tangga, (Surabaya: Ampel Mulia Surabaya, 2009), hlm. 198.

${ }^{3}$ Ramayulis, Samsul Nizar, Filsafat Pendidikan Islam: Telaah Sistem dan pemikiran para tokohnya, (Jakarta: Kalam Mulia, 2009) hlm. 182

${ }^{4}$ Mulyadhi Kartanegara, Mozaik Khazanah Islam, Bunga Rampai dari Chicago, (Jakarta: Paramadina, 2000), hlm. 75

${ }^{5}$ Abdullah Nâshih Ulwan, Tabîyah Al-Aulad Fi al-Islam (Pendidikan Anak Dalam Islam) Terj. Jamaluddin Miri, (Jakarta: Pustaka Amani, 2007), Jilid 1, hlm. XXIV
} 
memiliki pribadi maupun akhlak yang baik, yang semua itu dimulai dari anak di dalam kandungan hingga kelak anak dewasa di dalam menentukan arah tujuan hidupnya. Namun yang menjadi permasalahan tidak semua anak mendapatkan pendidikan akhlak lansung dari orang tuanya, hal itu disebabkan ada sebagian anak yang kurang beruntung, yaitu anak yatim, piatu, maupun anak yang ditelantarkan oleh kedua orang tuanya, maka sudah semestinya itu merupakan tanggung jawab kita bersama, agar anak-anak terhindar dari hal-hal yang akan merusak masa depannya.

Sebagaimana juga, dijelaskan dalam Al-Qur'an surah An-Nisa ayat 9 yang berbunyi:

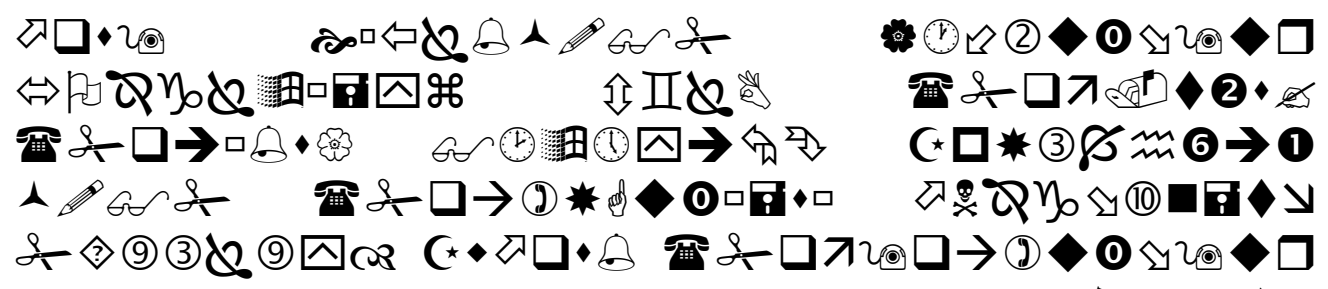

$$
\text { ( } 9 \text { : النساء }
$$

Artinya:Dan hendaklah takut kepada Allah SWT orang-orang yang seandainya meninggalkan dibelakang mereka anak-anak yang lemah, yang mereka khawatir terhadap (kesejahteraan) mereka. oleh sebab itu hendaklah mereka bertakwa kepada Allah SWT dan hendaklah mereka mengucapkan Perkataan yang benar. (Q.S 4:9). ${ }^{6}$

Ayat di atas memberikan gambaran tentang hati orang tua yang amat sensitif terhadap anak-anaknya, dengan tidak ada orang yang menaruh kasih sayang dan melindunginya. ayat tersebut juga memberikan penjelasan bahwa begitu rapuhnya akhlak seorang anak-anak terutama anak yatim maupun yang ditinggalkan oleh orang tuanya. Maka jika mendapat amanat dalam mengurusi anak-anak (yatim) di mana hendaknya mengurusi serta menanamkan kepada anakanak tersebut nilai-nilai ketakwaan, perhatian, dan kasih sayang. Selannjutnya juga mengucapkan perkataan yang baik kepada mereka maupun memeliharanya sebagaimana memelihara harta mereka. ${ }^{7}$ Oleh sebab itu para pendidik hendaknya mempersiapkan generasi penerus yang berkualitas sehingga anak mampu mengaktualisasikan potensinya sebagai bekal kehidupan di masa akann datang.

\footnotetext{
${ }^{6}$ Departemen Agama, Al-Qur'an dan Terjemahannya, (Jakarta: Pustka Al-Fatih, 2005), hlm. 78

${ }^{7}$ Sayyid Quthb, Tafsir Fi Zhilalil Qur'an: Di Bawah Naungan Al-Qur'an, (Jakarta:
} Gema Insani Press, 2001), hlm. 286-287. 
Sebagaimana gambaran ayat di atas di mana tersirat makna bahwa seseorang hendaknya senantiasa memperhatikan anak-anak kita terutama anak yatim, di mana jangan sampai mereka lemah, baik dari segi fisik maupun dari mental serta senantiasa memperhatikan sikap maupun perilakunya agar kelak mereka terhindar dari hal-hal yang merugikan orang lain maupun dirinya serta terhindar dari perbuatan-perbuatan yang bertentangan dengan nilai-nilai ajaran Islam.

Hal itu disebabkan karena akhlak menempati posisi yang sangat penting dalam Islam, akhlak dengan taqwa merupakan "buah" pohon Islam yang berakarkan akidah, bercabang dan berdaun syariah, pentingnya kedudukan akhlak, dapat dilihat dari berbagai sunnah Qauliyah (Sunnah dalam bentuk perkataan). ${ }^{8}$

Akhlak merupakan kelakuan yang timbul dari hasil perpaduan antara hati nurani, pikiran, perasaan, bawaan, dan kebiasaan yang menyatu, membentuk suatu kesatuan tindak akhlak yang dihayati dalam kenyataan hidup keseharian. Dari kelakuan itu lahirlah perasaan moral yang terdapat di dalam diri manusia sebagai fitrah, sehingga anak mampu membedakan mana yang baik dan mana yang jahat, mana yang bermanfaat dan yang mana yang tidak berguna, mana yang cantik dan mana yang buruk. Dari sana timbul bakat akhlak yang merupakan kekuatan jiwa dari dalam yang mendorong manusia untuk melakukan yang baik dan mencegah perbuatan yang buruk. Allah SWT mendorong manusia untuk memperbaiki akhlaknya bila anak terlanjur salah. ${ }^{9}$

Maka wajar pada saat sekarang kemerosotan akhlak pada anak-anak remaja dapat dilihat dengan banyaknya anak yang berkata kasar maupun berperilaku tidak sopan kepada orang tua, merokok, berjudi, minuma miras, pergaulan bebas dan lain sebagainya, bahkan sudah merupakan hal biasa di jumpai di lingkungan sekitar tempat kita tinggal, memerintah orangtua seperti memerintah teman, memanggil seseorang dengan gelar yang buruk bahkan ada yang sampai memakai nama hewan untuk memanggil seseorang. Para anak banyak yang sibuk bekerja, sedangkan orang tua hanya sibuk menjaga anakanaknya, sehingga yang seharusnya orang tua lebih banyak beribadah kepada

\footnotetext{
${ }^{8}$ Mohammad Daud Ali, Pendidikan Agama Islam, (Jakarta: Rajawali Pers, 2008), hlm. 348.

${ }^{9}$ Zakiah Daradjat, Pendidikan Islam Dalam Keluarga dan Sekolah, (Jakarta: Ruhama, 1995), hlm. 10.
} 
Allah SWT, tetapi malah sibuk mengurus anak-anaknya. Selanjutnya pada saat sekarang sering kita temukan hubungan keluarga kurang dipandang jika tergolong kategori keluarga miskin, di mana status dipandang dari segi ekonomi atau harta, kedudukan, jabatan maupun hal-hal yang bersifat kemewahan, sehingga etika sopan santun akan terlihat jika kemewahan terdapat pada orang tersebut. Tetapi jika sebaliknya maka kesopanan kurang terlihat karena sifat negatif telah tertanam dalam diri anak tersebut.

\section{METODE PENELITIAN}

Jenis penelitian menggunakan pendekatan deskriptif kualitatif yang penulis gunakan adalah library research yaitu mengumpulkan buku-buku yang berkaitan dengan objek penelitian atau penelitian yang bersifat kepustakaan.

1. Sumber Data

Kajian yang penulis gunakan adalah penelitian perpustakaan murni, penulis akan menggunakan dua sumber, yaitu:

a. Sumber Primer

Sumber data yang berifat primer adalah buku rujukan awal dan utama dalam penelitian, sumber primer yang penulis gunakan adalah :

i. Amirulloh Syarbini dan Akhmad Khusaeri, Kiat-Kiat Islami Mendidik Akhlak Remaja, (Jakarta, Gramedia, 2012)

\section{b. Sumber Sekunder}

Sumber sekunder adalah hasil pengumpulan yang dilakukan oleh orang lain dengan maksud tertentu dan mempunyai kategori atau klasifikasi menurut keperluan masing-masing dan kegunaan bagi peneliti masingmasing. ${ }^{10}$ Dalam hal ini Sumber data yang berifat sekunder adalah buku rujukan pendukung dalam penelitian, sumber sekunder yang penulis gunakan adalah :

${ }^{10}$ S. Nasotion, Metode Research Penelitian Ilmiah, (Jakarta: Bumi Aksara, 2002), Cet. 5, h. 143 
i. Abdullah Nâshih Ulwan, Tabîyah Al-Aulad Fi al-Islam (Pendidikan Anak Dalam Islam) Terj. Jamaluddin Miri, (Jakarta: Pustaka Amani, 2007), Jilid 1

ii. Departemen Agama, Al-Qur'an dan Terjemahannya, (Jakarta:

Pustka Al-Fatih, 2005)

iii. Moeslichatoen R, Metode Pengajaran di Taman Kanak-Kanak, (Jakarta: Rineka Cipta, 2004)

iv. Musa Turoichan, Kado Perkawinan, Kiat Menciptakan Surga Dalam Rumah Tangga, (Surabaya: Ampel Mulia Surabaya, 2009)

v. Mohammad Daud Ali, Pendidikan Agama Islam, (Jakarta: Rajawali Pers, 2008)

vi. Zakiah Daradjat, Pendidikan Islam Dalam Keluarga dan Sekolah, (Jakarta: Ruhama, 1995)

2. Teknik Pengumpulan Data

Teknik pengumpulan data adalah cara-cara yang digunakan oleh peneliti untuk mengumpulkan data. ${ }^{11}$ Pengumpulan data dalam penelitian ini adalah dengan cara dokumentasi. Dokumentasi adalah "ditujukan untuk memperoleh data langsung dari tempat penelitian, meliputi bukubuku yang relevan, peraturan-peraturan, laporan kegiatan, foto-foto, fim, dokumenter, data yang relevan penelitian". ${ }^{12}$

3. Teknik Analisa Data

Teknik analisa data adalah cara penghitungan untuk menjawab rumusan masalah dan pengujian hipotesis yang diajukan. ${ }^{13}$ Hipotesis adalah jawaban sementara yang harus di uji kebenarannya. Namun, penelitian yang penulis gunakan dengan kajian pustaka (library research) ini, maka penulis menggunakan tekhnik analisa data kajian isi (countent analysis).

2013), Cet. Ke-10, h. 24

11 Riduwan, Skala Pengukuran Variabel-Variabel Penelitian, (Bandung: Alfabeta,

${ }^{12}$ Ibid., h. 31

13 Riduan, Belajar Mudah Penelitian Untuk Guru, Karyawan Dan Peneliti Pemula, (Bandung: Alfabeta, 2015). h. 12 
Kajian ini adalah kajian yang menanfaatkan buku atau dokumen untuk menarik kesimpulan, baik kajian isi yang bersifat deduktif maupun kajian isi yang bersifat induktif. ${ }^{14}$ Pada kajian ini peneliti terlebih dahulu mengadakan survei data untuk memperoleh informasi dari penelitian terdahulu terhadap pengerjaan tanpa memperdulikan apakah data itu primer atau sekunder, di lapangan atau dilaboratorium. Kemudian, menelusuri leteratur yang ada serta mentelaahnya secara tekun. Setelah itu, peneliti mengungkapkan buah pikiran secara kritis dan analistis. ${ }^{15}$

\section{PEMBAHASAN}

Amirulloh Syarbini, lahir di Celegon Banten pada tangga 13 Juni 1980. Menyelesaikan S.1 di IAIN Sunan Gunung Djati tahun 2003. Kemudian melanjutkan ke program pascasarjana S.2 di Universitas Islam Negeri Sunan Gunung Djati dan lulus tahun 2006. Sehari-hari Amirulloh Syarbini bekerja sebagai Dosen di Fakultas Tarbiyah dan keguruan Universitas Islam Negeri Sunan Gunung Djati dan sekolah Tinggi Agama Islam Al-Musdariyah kota Cimahi. Selain sebagai dosen Amirulloh Syarbini juga sering tampil sebagai penceramah, instruktur seminar, dan trainer pelatihan-pelatihan motivasi diberbagai instansi pemerintahan dan lembaga pendidikan di Indonesia.

Sejak tahun 2010, Amirulloh Syarbini terjun kedunia penulisan dan melahirkan beberapa buku diantaranya doa-doa khusus wanita, keajaiban sholat, sedekah dan silaturrahmi, 11 Ibadah dahsyat pelancar rezeki, Al-Qur'an dan kerukunan hidup umat beragama, rahasia sukses menjadi pembicara hebat, doadoa khusus ibadah haji, kiat-kiat mendidik akhlak remaja: panduan pintar mendidik akhlak remaja manurut Islam. ${ }^{16}$

Riwayat Hidup Khusaeri lahir di Cerebon pada tanggal 28 Juli 1981. Akhmad Khusaeri menyelesaikan S.1 di jurusan pendidikan agama Islam IAIN Sunan Gunung Djati tahun 2003, selanjutnya melanjutkan S.2 di Universitas Islam Nusantara (UNINUS) Bandung dengan konsentrasi Manajemen pendidikan dan

${ }^{14}$ Lexy J. Moleong, Metodologi Penelitian Kualitatif (Bandung:Remaja Rosdakarya, 2013), Cet. 31, h. 220

${ }^{15}$ Moh. Nazir, Metode Penelitian, (Bogor Selatan: Ghalia Indonesia, 2005), h. 93

${ }^{16}$ Amirulloh Syarbini dan Akhmad Khusaeri, Op., Cit h. 113 
tahun 2010 dengan predikat Cumlaude. Sehari-hari Akhmad Khusaeri bekerja sebagai guru SDIT Nur Al-Rahman dan Dosen di STAI Al-Musdariyah kota Cimahi dan STIT At-Taqwa Geger Kalong Kota Bandung. Selain itu, Akhmad Khusaeri juga aktif sebagai kolumnis beberapa koran lokal dan nasional, seperti pikiran rakyat, Republika, dan sebagainya, serta menulis beberapa buku salah satunya mengenai Al-Qur'an dan Kerukunan Hidup Umat Beragama. ${ }^{17}$

\section{Pemikiran Amirulloh Syarbini Dan Akhmad Khusaeri Tentang Pendidikan} Akhlak Remaja.

Secara etimologis kata "remaja" dalam bahasa indonesia sebenarnya terjemahan dari bahasa inggris "Pubertas/puberity)" yang berarti rambut kemaluan, yaitu suatu tanda kelamin sekunder yang menunjukkan perkembangan seksual seseorang. Dari bahasa Latin "Adolesen atau adolescentia” yang berarti menjadi dewasa atau dalam perkembangan menjadi dewasa. Dalam kamus Umum Bahasa Indonesia remaja diartikan dengan mulai dewasa (mulai muncul rasa cinta birahi).

Sedangkan secara terminologis menurut Zakiah Daradjad yang dikutip oleh Amirulloh Syarbini dan Akhmad Khusaeri, mengatakan bahwa remaja diartikan sebagai anak yang ada masa peralihan dari masa anak-anak menuju usia dewasa. Pada masa peralihan ini biasanya terjadi percepatan pertumbuhan dalam segi fisik dan psikis, baik ditinjau dari bentuk badan, sikap, cara berpikir, dan bertinda. Mereka bukan lagi anak-anak, namun mereka juga belum bisa dikatakan manusia dewasa yang memiliki kematangan berpikir. ${ }^{18}$

Pendidikan akhlak bagi remaja adalah upaya (bimbingan, arahan, pengajaran, dan lain sebagainya), yang dilakukan oleh pendidik secara sengaja dan sistematis, untuk membentuk karakter dan kepribadian remaja agar memiliki dan melakukan perbuatan baik serta menjauhi perbuatan buruk dengan penuh kesadaran tanpa ada paksaan dari siapapun. Dengan kata lain, pendidikan akhlak bagi remaja adalah suatu proses bimbingan untuk membina dan mangarahkan perangai dan tingkah laku remaja sesuai ajaran Islam demi terwujudnya akhlak

\footnotetext{
${ }^{17}$ Ibid., h. 114

${ }^{18}$ Ibid., h. 2
} 
mulia. Selanjutnya pendidikan akhlak sifatnya integratik bukan monolitik, artinya pendidikan tidak berdiri sendiri, bukan mata pelajaran atau jenis studi, tetapi terintegrasi dalam setiap jenis sistem, dan model pendidikan manapun, baik pendidikan formal, informal maupun non formal. ${ }^{19}$

Pendidikan akhlak merupakan alat pembinaan yang sangat ampuh bagi remaja. Akhlak yang tertanam dan tumbuh secara wajar dalam jiwa remaja akan dapat digunakannya untuk mengendalikan keinginan dan dorongan yang kurang baik serta membantunya dalam menghadapi berbagai masalah kehidupan pada umumnya. Dengan pendidikan akhlak akan terwujud remaja ideal, yaitu remaja yang bertaqwa kepada Allah SWT, dan cerdas, serta diharapkan mampu menyempurnakan nilai-nilai kemanusian sesuai dengan ajaran Islam dan taat beribadah dan sanggup hidup bermasyarakat secara baik.

Dalam dunia pendidikan, pembinaan akhlak diutamakan kepada pembentukan mental anak atau remaja agar tidak mengalami penyimpangan. Dengan demikian akan mencegah terjadinya kenakalan remaja. Sebab pembinaan akhlak berarti anak remaja dituntun agar memiliki rasa tanggung jawab. Dengan pendidikan akhlak terhindarnya anak-anak remaja dari tabiat tercela dan sebagi langkah penanggulangan terhadap timbulnya kenakalan remaja. Dengan demikian pendidikan akhlak dapat memberikan sumbangan positif bagi ketenteraman dan keamanan masyarakat dari kejahatan pada umumnya, terutama gangguan dari kenakalan remaja. Sebab pada hakikatnya kejahatan yang dilakukan orang dewasa merupakan perkembangan lebih lanjut dari kebiasaan melakukan kejahatan diwaktu kecil, atau pada masa-masa perkembangan mental, yakni masa remaja. Oleh sebab itu ruang lingkup pendidikan akhlak adalah membentuk remaja yang berakhlak mulia, sopan dalam berbicara, bertindak bijaksana, beradab mulia dalam tingkah laku, memegang teguh perangai yang baik, menjauhkan diri dari perangai yang jahat, kemauan keras untuk belajar, dan taat beribadah kepada Allah SWT. ${ }^{20}$

Berdasarkan penjelasan di atas maka dapat disimpulkan bahwa pendidikan akhlak merupakan sebuah usaha dari seorang pendidik membimbing, mendidik, memberikan pengajaran dalam membentuk seseorang agar memiliki akhlak yang

${ }^{19}$ Ibid., h. 36
${ }^{20}$ Ibid. h. 37 
baik dengan mengacu kepada nilai-nilai ajaran agama Islam, sehingga kelak anak mampu membedakan mana yang baik, dan mana yang buruk. Selanjutnya dengan pendidikan akhlak anak terhindar dari hal-hal yang merusak masa depannya maupun anak mampu mempergunakan sikap, tingkah laku, pola berpikirnya sesuai dengan situasi dan kondisi yang anak lalui maupun yang sedang dihadapinya. Maka sebagai pendidik khususnya orangtua hendaknya memperhatikan pendidikan akhlak sedini mungkin serta selalu senantiasa mengawasi tingkah laku anak dan yang pasti memberikan pendidikan akhlak kepada anak merupakan sebuah keharusan yang mutlak harus dilakukan agar anak memiliki arti dalam menjalani kehidupannya di masa akan datang.

\section{Metode Dalam Mendidik Akhlak Remaja}

Keberhasilan proses pendidikan dalam mengantarkan anak mencapai tujuan yang diharapkan, tidak terlepas dari peranan metode yang digunakan. Metode adalah cara berfikir menurut sistem tertentu. Metode juga diartikan sebuah prosedur yang dipakai untuk mencapai tujuan tertentu. Sedangkan dalam konteks pendidikan akhlak, metode berarti semua upaya, prosedur, dan cara yang ditempuh untuk menanamkan akhlak pada diri remaja. Dalam proses pendidikan metode mempunyai kedudukan sangat penting guna mencapai tujuan pendidikan. Oleh karena itu, diperlukan kehati-hatian dalam menentukan metode. Sebab jika salah mengambil suatu metode, tujuan pendidikan tidak akan tercapai bahkan akan membawa mudharat terhadap anak didik. ${ }^{21}$ Menurut Islam, ada beberapa metode yang digunakan untuk mendidik ahlak remaja antara lain. :

a. Mendidik Melalui Keteladanan.

Konsep dan persepsi pada diri seorang anak remaja dipengaruhi oleh unsur dari luar diri mereka. Hal ini terjadi karena sejak usia dini telah melihat, mendengar, mengenal dan mempelajari hal-hal yang berada diluar diri mereka. Mereka telah melihat dan mengikuti apa-apa yang dikerjakan dan diajarkan orang dewasa dan orangtua mereka tentang sesuatu. Sejak fase-fase awal kehidupan seorang anak remaja banyak sekali belajar melalui peniruan terhadap kebiasaan dan tingkah laku orang-orang disekitarnya. Salah satu

\footnotetext{
${ }^{21}$ Ibid., h. 44
} 
diantaranya dari orang-orang yang dianggap sebagai idola, selain orangtuanya itu sendiri, kebiasaan meniru dan belajar melalui peniruan masih sangat kental dalam kehidupan anak remaja, sehingga hal ini menjadikan keteladanan sangat penting dalam mendidik anak usia remaja.

Agar seorang anak meniru sesuatu yang positif dari orangtua, guru, ataupun orang yang dianggap diidolakan, menjadi kemestian mereka itu semua harus menjadikan dirinya Uswatun Hasanah dengan menampilkan diri sebagai sumber normal, budi yang luhur dan perilaku yang mulia. Pentingnya keteladanan dalam mendidik anak, termasuk anak remaja menjadi pesan kuat dari Al-Qur'an. Sebab keteladan adalah sarana penting dalam pembentukkan karakter seseorang. Satu kali perbuatan baik dicontohkan lebih baik dari seribu kata yang diucapkan.

Oleh karena itu, keteladanan dalam mendidik anak remaja adalah sangat penting, apalagi sebagai orangtua yang diamanahi Allah SWT berupa anakanak, maka orangtua harus menjadi teladan yang baik buat anak-anak. Orangtua harus bisa menjadi figur yang ideal bagi anak-anak. Orangtua harus menjadi panutan yang bisa diandalkan oleh anak-anak dalam mengarungi kehidupan ini. Jadi jika menginginkan anak-anak mencintai Allah SWT dan Rasul-Nya, maka sebagai orangtua harus terlebih dahulu mencintai Allah SWT dan Rasul-Nya, sehingga kecintaan itu akan terlihat oleh anak-anak. ${ }^{22}$

b. Mendidik Melalui Perhatian.

Dalam masa pertumbuhan menjadi manusia dewasa, kaum remaja memerlukan perhatian khusus dalam masalah emosi. Hal ini sangat beralasan, karena gangguan atau kekacauan mental dan emosional yang terjadi pada siapapun termasuk pada kaum remaja bisa menimbulkan stres. Pada usia ini bimbingan orangtua menjadi hal yang mutlak, mengingat emosi anak remaja yang masih labil dan efek kelanjutan yang mungkin timbul akibat dari gangguan tersebut.

Anak adalah amanat bagi orangtuanya, para orangtua bertanggung jawab atas pendidikan, agama, dan akhlak anak-anaknya. Anak-anak yang baik akan menjadi permata hati bagi mereka di dunia dan di akhirat. Lantas bagaimana

\footnotetext{
${ }^{22}$ Amirulloh Syarbini dan Akhmad Khusaeri, Kiat-Kiat Islami Mendidik Akhlak Remaja, (Jakarta, Gramedia, 2012), h. 45
} 
memaksimalkan perhatian kepada anak, sehingga kondisi labil dan ancaman stres yang sering datang kapan saja dapat ditangani dengan baik. Bahkan para orangtua mesti mengetahui dengan siapa anak berteman, dilingkungan mana anak bergaul, dengan seperti itu perkembangan anak dalam pembinaan akidah, moral, spritual, dan sosial serta jasmani dan daya ilmiahnya terperhatikan dengan maksimal. Berikut hal-hal yang perlu diperhatikan oleh orangtua dalam mendidik anak remajanya adalah:

1) Menanamkan aqidah yang kuat, diawali dengan pembinaan prinsip-prinsip awal sebagai pondasi keimanan.

2) Memperhatikan moral. Hal ini bisa diwujudkan dengan menanamkan dan membiasakan kejujuran amanah dan akhlak yang baik, serta memilihkan teman bergaul, lingkungan dan bahan bacaan yang baik.

3) Memperhatikan mental anak. Hal ini bisa direalisasikan dengan membentengi anak sejak awal dari kebiasaan buruk.

4) Memperhatikan sisi kejiwaan. Jika anak mengalami gejala minder, pemarah atau pendiam harus ditelusuri penyebabnya.

5) Memperhatikan segi sosial. Orangtua hendaknya memantau anak tentang pemenuhan hak orang lain, memiliki sifat empati, rendah hati, belas kasih, santun dan bertanggung jawab.

6) Memperhatikan segi spritual. Diwujudkan dengan mengusahakan agar anak memiliki sifat khusuk dalam beribadah, rajin dan semangat dalam melaksanakan aktivitas hariannya.

7) Memperhatikan jasmani. Diwujudkan dengan memberi makanan halal dan baik, menciptakan rumah yang sehat, bersih, membiasakan olahraga, menjaga pola makan dan hidup teratur.

8) Memperhatikan dari segi intelektual. Orangtua hendaknya membimbing dan melatih anak dengan penuh kesabaran dalam belajar, membiasakan membaca Al-Qur'an serta memupuk daya ilmiahnya dengan berbagai ilmu pengetahuan. $^{23}$

c. Mendidik Melalui Kasih Sayang.

${ }^{23}$ Ibid., h. 47 
Kasih sayang menciptakan kerjasama di antara manusia. Bila kasih sayang tidak ada, maka tidak akan terwujud persaudaraan diantara manusia, tak seorang pun yang merasa memiliki tanggung jawab terhadap orang lain. Oleh sebab itu, sikap kasih sayang sesama manusia, khususnya dalam mendidik adalah hal yang esensial (perlu sekali). Di samping itu, kasih sayang juga menyebabkan lahirnya rasa aman dan nyaman, baik secara jasmani maupun rohani, dan menjadi solusi tepat dalam memperbaiki perilaku amoral dan mengharmoniskan hubungan manusia.

Maka jelaslah bahwa hubungan antar sesama manusia khususnya anakanak harus berdasarkan bahasa cinta dan kasih sayang. Begitupun dengan dunia pendidikan akan sukses dan makmur kalau berbagai jenjangnya ditempuh dengan irama cinta. Perlu diingat kembali, manusia secara alami membutuhkan kasih sayang. Hanya kasih sayang yang mampu mengubah perilaku seseorang. Kasih sayang merupakan sumber pendidikan jiwa, dan bukanlah perkara yang mudah mengubah hati yang keras menjadi lembut, namun kasih sayang telah terbukti manjadi resep yang manjur dalam mengarahkan hati seseorang, dan mengontrolnya serta mampu mencegahnya dari perbuatan tercela dan hina. Bahkan kasih sayang dapat merubah manusia yang semula tanpak sederhana dan kurang diperhitungkan menjadi insan seutuhnya, jujur dan benar.

Anak-anak, kalangan remaja hingga kalangan orang dewasa pun samasama membutuhkan cinta dan kasih sayang. Di mana kasih sayang merupakan hal yang sangat penting dalam sistem pengajaran dan pendidikan anak-anak. Ketika seorang anak melihat ikatan kasih sayang pada kedua orangtuanya, hal ini sedikit banyak berpengaruh dalam menjauhkan dari perbuatan tercela. Memberikan kasih sayang merupakan metode yang sangat berpengaruh dan efektif dalam mendidik anak, sebab kasih sayang memiliki daya tarik dan memotivasi akhlak yang baik, serta memberikan ketenangan kepada anak yang nakal sekalipun. Rasa cinta dan kasih sayang harus terlebih dahulu menjadi jaminan ketenangan dan kedamaian anak-anak di lingkungan keluarga sebelum mereka berhadapan dengan berbagai aturan dan keputusan yang dibuat oleh orangtua. 
Kebahagian dan ketenangan jiwa mereka akan terpenuhi jika sebuah keluarga dapat menjadi pusat ekspresi perasaan, kasih kayang dan kecintaan. Apabila yang ayah dan ibu tidak mampu memenuhi kebutuhuan yang perlu ini, maka anak akan tumbuh kurang percaya diri sehingga di masa depan akan muncul berbagai penyimpangan individual dan sosial. Oleh karena itu, lingkungan keluarga harus diwarnai dengan kehangatan cinta dan kemesraan hubungan antar keluarga, sehingga seorang anak juga berusaha dan berupaya memberikan kehangatan cinta pada lingkungan keluarganya. Kasih sayang mampu mengatasi segala persoalan dalam pendidikan. Semua pekerjaan, khususnya kerja yang berkaitan dengan pemikiran dan budaya butuh akan cinta. Sebuah pekerjaan harus dilakukan dengan senyuman, tidak dengan pemaksaan dan kekerasan. ${ }^{24}$

d. Mendidik Melalui Nasehat.

Fase ramaja merupakan masa perkembangan individu yang sangat penting. Pada masa remaja sering ditandai dengan adanya perubahan baik secar fisik maupun fsikis, yang mungkin saja dapat menimbulkan problema tertentu bagi remaja apabila tidak disertai dengan pemahaman diri dan pengarahan diri secara tepat, bahkan menjurus kepada berbagai tindakan kenakalan remaja dan kriminal. Problema yang mungkin timbul pada masa remaja diantaranya:

1) Perkembangan fisik dan motorik

Pada masa remaja ditandai dengan adanya pertumbuhan fisik yang cepat. Kematangan organ reproduksi pada masa remaja membutuhkan upaya pemuasan, dan jika tidak terbimbing oleh norma-norma dapat menjurus kepada penyimpangan perilaku seksual.

2) Perkembangan kognitif dan bahasa

Tidak bisa dipungkiri bahwa dalam era globalisasi sekaran ini, penguasaan bahasa asing merupakan hal yang penting untuk menunjang kesuksesan hidup dan karir seseorang. Namun dengan adanya hambatan dalam pengembangan ketidakmampuan berbahasa asing tentunya akan sedikit banyak berpengaruh terhadap kesuksesan hidup dan karirnya. Terhambatnya

${ }^{24}$ Ibid., h. 52 
perkembangan kognitif dan bahasa dapat berakibat pula pada aspek emosional, sosial, dan aspek-aspek perilaku dan kepribadian lainnya.

3) Perkembangan perilaku sosial, moralitas dan perkemabangan.

Problema perilaku sosial remaja tidak hanya terjadi pada kelompok sebayanya, namun juga dapat terjadi dengan orangtua dan dewasa lainnya, termasuk dengan guru di sekolah. Hal ini disebabkan pada masa remaja, khususnya remaja awal akan ditandai adanya keinginan yang ambivalen (saling bertentangan). Disatu sisi adanya keinginan untuk melepaskan kebergantungan dan dapat menentukan pilihannya sendiri, namun disisi lain masih membutuhkan orangtua, terutama secara ekonomis.

4) Perkembangan kepribadian dan emosional

Timbulnya problema remaja dipengaruhi oleh beberapa faktor, baik bersifat internal maupun eksternal agar remaja dapat terhindar dari berbagai kesulitan dan problema yang memerlukan kearifan dari semua pihak. Upaya untuk memfasilitasi perkembangan remaja menjadi amat penting. Dalam hal ini, peranan orangtua, sekolah, serta masyarakat sangat diharapkan. Peranan itu salah satunya bisa diwujudkan dengan selalu menasehati anak remaja kita, tentunya dengan bahasa yang bijak dan menghilangkan kesan mengatur mereka, akan tidak terjadi resistensi dari mereka. Metode nasehat merupakan penyampaian kata-kata yang menyentuh hati dan disertai dengan keteladanan. $^{25}$

e. Mendidik Melalui Curhat.

Satu hal lain dari ciri perkembangan sekaligus permasalahan yang sering muncul pada remaja adalah berkenaan dengan perasaan sebagai seseorang yang menginjak remaja yang sejalan dengan perkembangan seksualnya. Perkembangan seksual seorang anak biasanya bersamaan dengan perkembangan organ-organ seksual dan jaringan saraf yang sangat penting dalam perkembangan rasionya. Perubahan-perubahan tersebut disertai dengan gejala-gejala khusus dalam tingkah laku yang menuntut perhatian dan pengawasan. Oleh sebab itu, orangtua wajib menjadikan doa sebagai salah satu

\footnotetext{
${ }^{25}$ Ibid., h. 57
} 
sarana penyembuh penyakit hati atau saat mendengarkan keluh kesah (curhat) anaknya atau peserta didiknya. ${ }^{26}$

f. Mendidik Melalui Pembiasaan.

Manusia dilahirkan dalam keadaan suci dan bersih, dalam keadaan seperti manusia akan mudah menerima kebaikan atau keburukan, pembiasan perilaku seperti melaksanakan nilai-nilai ajaran agama Islam (beribadah), membina hubungan atau interaksi yang harmonis dalam keluarga memberikan bimbingan, arahan, pengawasan dan nasehat merupakan hal yang senantiasa harus dilakukan oleh orangtua agar perilaku remaja yang menyimpang dapat dikendalikan.

Dalam pendidikan dan pembinaan akhlak melalui pola pembiasaan bagi para remaja, orangtua harus dapat berperan sebagai pembimbing spritual yang mampu mengarahkan dan memberikan contoh teladan, menuntun, mengarahkan dan memperhatikan akhlak remaja, sehingga para remaja berada pada jalan yang baik dan benar. Jika remaja melakukan kesalahan, orangtua dengan arif dan bijaksana membetulkannya. Begitu juga sebaliknya jika remaja melakukan sesuatu perbuatan yang terpuji, orangtua wajib memberikan dorongan dengan perkataan atau pujian maupun dengan hadiah yang berbentuk benda.

Oleh karena itu, peranan keluarga sangat besar dalam membina akhlak remaja dengan pola apapun. Dengan pembiasaan salah satunya dapat mengantarkan kearah kematangan dan kedewasaan, sehingga remaja dapat mengendalikan dirinya, menyelesaikan persoalan serta menghadapi tantangan dalam hidupnya. Untuk membina akhlak tersebut, orangtua perlu menerapkan disiplin dalam menjalani kehidupan sehari-hari. Disiplin yang ditanamkan orangtua merupakan modal dasar yang sangat penting bagi remaja untuk menghadapi berbagai persoalan pada masa remaja. ${ }^{27}$

g. Mendidik Melalui Cerita Dan Kisah.

${ }^{26}$ Ibid., h. 62

${ }^{27}$ Ibid., h. 66 
Bercerita adalah suatu kegiatan yang dilakukan oleh orangtua atau guru di sekolah pada muridnya, ayah kepada anaknya, guru bercerita pada pendengarnya. Suatu kegiatan yang bersifat seni karena erat kaitannya dengan keindahan dan bersandar kepada kekuatan kata-kata yang dipergunakan untuk mencapai tujuan cerita. Jadi metode bercerita merupakan salah satu metode yang bisa digunakan dalam mendidik anak usia remaja. Sebagai suatu metode, bercerita mengundang perhatian anak terhadap pendidik sesuai dengan tujuan mendidik. Apabila isi cerita dikaitkan dengan dunia kehidupan remaja, mereka dapat memahami isi cerita itu. Mereka akan mendengarkannya dengan penuh perhatian, dan dengan mudah dapat menangkap isi cerita.

Menurut Moeslichatoen $\mathrm{R}$ Metode bercerita adalah "pemberian pengalaman belajar dengan membawakan cerita lisan, dengan cerita yang menarik dan mengandung nilai pendidikan". ${ }^{28}$ Tapi yang perlu diingat, bahwa bercerita bukan hanya berfungsi sebagai hiburan, tetapi juga merupakan suatu cara yang dapat digunakan dalam mencapai sasaran atau target pendidikan. Selain itu, mendidik dengan metode cerita atau kisah, juga dapat menjadikan suasana belajar menyenangkan dan mengembirakan dengan penuh dorongan dan motivasi, sehingga pelajaran atau materi pendidikan dapat dengan mudah diberikan. $^{29}$

Tujuan disampaikannya metode bercerita adalah:

1. Memberikan informasi atau menanamkan nilai-nilai sosial, moral dan keagamaan, pemberian informasi tentang lingkungan fisik dan lingkungan sosial.

2. Anak mampu mendengarkan dengan seksama terhadap apa yang disampaikan oleh orang lain.

3. Anak dapat bertanya apabila tidak memahaminya.

4. Anak dapat menjawab pertanyaan.

5. Anak dapat menceritakan dan mengekspresikan terhadap apa yang didengarkan dan diceritakannya, sehingga hikmah dari isi cerita dapat

${ }^{28}$ Moeslichatoen R, Metode Pengajaran di Taman Kanak-Kanak, (Jakarta: Rineka Cipta, 2004), hlm. 157.

${ }^{29}$ Ibid., h. 69 
dipahami dan lambat laun didengarkan, diperhatikan, dilaksanakan dan diceritakannya pada orang lain. ${ }^{30}$

h. Mendidik Melalui Penghargaan Dan Hukuman.

Dalam Islam, metode Reward dan Punishment sangat dianjurkan dalam mendidik anak, terutama dalam membentuk akhlak remaja. Di mana para pendidik khususnya orangtua perlu memberikan penghargaan kepada anak sesuai dengan apa yang diajarkan Islam, diantaranya:

1) Dengan ungkapan kata (pujian)

2) Dengan memberikan hadiah.

3) Dengan memberikan senyuman atau tepukan.

4) Dengan mendoakannya.

5) Menunjukkan kebaikannya.

6) Menganggap diri kita bagian dari mereka. ${ }^{31}$

Selanjutnya yang perlu diperhatikan oleh para pendidik, di mana harus mampu menghindari hukuman yang dapat menimbulkan kemudharatan terhadap anak. Para pendidik juga hendaknya menjauhi bentuk-bentuk hukuman fisik, karena ini membahayakan, baik bagi diri anak, maupun bagi diri pendidik sendiri. Oleh karena itu, penggunaan hukuman fisik hendaknya dijauhi kecuali dalam keadaan yang benar-benar memaksa. Misalnya mendidik anak-anak bandel yang tidak berhasil selain dengan cara hukuman fisik, atau untuk menjaga kewibawaan serta kelancaran jalannya kegiatan belajar mengajar. $^{32}$

Berdasarkan penjelasan di atas maka dapat disimpulkan bahwa metode merupakan sebuah cara atau yang perlu diketahui oleh seorang pendidik khususnya para orangtua dalam memberikan pendidikan akhlak kepada anak remaja. Namun semua itu merupakan sebuah pilihan, diterapkan atau tidak tergantung kepada orangtuanya. Tetapi yang jelas Islam telah memberikan sebuah gambaran dalam memberikan pendidikan akhlak kepada anak remaja, maka selama para pendidik benar-benar yakin serta mau menerapkan metode

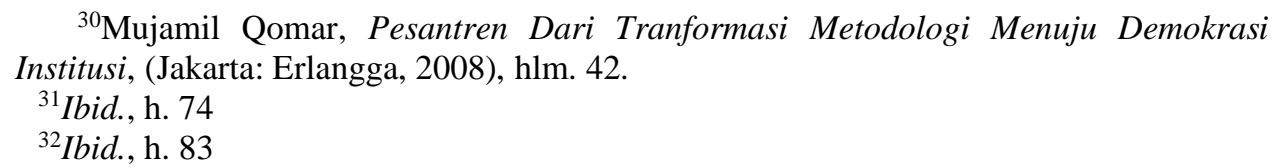


tersebut, sehingga tidak menutup kemungkinan akan membentengi anak-anak dari kerusakan-kerusakan yang akan menghampirinya kelak di masa akan datang.

Selain itu Islam menawarkan beberapa strategi atau kiat yang dianggap jitu dalam upaya pembentukan akhlak remaja. ${ }^{33}$ diantaranya sebagai berikut:

1. Hargai dan hormati remaja seperti mendengarkan pendapat atau usulan remaja merupakan salah satu bentuk penghargaan terhadap mereka, Cara lain menghargai remaja adalah tidak membanding-bandingkannya dengan orang lain.

2. Timbulkan pada remaja rasa disayang. Para orangtua dan guru serta semua pihak yang bertanggung jawab terhadap masa depan remaja, hendaknya memberikan perhatian yang besar kepada semua persoalan remaja dan sepatutnya meninggalkan perlakuan yang kasar terhadap mereka.

3. Bantulah Remaja Untuk Mendapatkan Rasa Aman Di Rumah, sebab rumah merupakan tempat yang paling nyaman bagi remaja guna melepaskan keletihan dan kelelahan baik fisik maupun psikis.

4. Tunjukkan Pengertian Dan Perhatian Kapada Remaja, di mana para pendidik harus mencurahkan, memperhatikan serta mengikuti perkembangan akidah, akhlak serta sosial anak ketika beradaptasi dengan lingkungannya.

5. Kenali Bakat Dan Minat Remaja, Minat dan bakat anak berbeda-beda, maka hargailah anak dengan segala kekurangan dan kelebihannya. Minat dan bakat anak sebenarnya sudah bisa terlihat sejak usia dini, anak biasanya akan beraksi lebih cepat dan aktif terhadap stimulus yang menjadi bakat dan minatnya.

6. Luangkan Waktu Khusus Untuk Remaja, Salah satu kesalahan orangtua dalam mendidik anak di zaman ini adalah mendidik disisa waktu. Orangtua zaman sekarang hanya jadi wekend Parent, orangtua yang hanya ada pada hari sabtu dan minggu. Bahkan tidak jarang orangtua yang hanya bersama anak-anaknya dengan waktu yang sangat terbatas, bagaimana bisa

\footnotetext{
${ }^{33}$ Ibid., h. 90
} 
membentuk anak yang cerdas dan berakhlak karimah, kalau hanya memiliki waktu yang terbatas dengan anak. Oleh karena itu, orangtua harus adil dalam membagi waktu, ada waktu untuk Allah SWT, ada waktu untuk diri sendiri, dan waktu untuk keluarga atau anak-anak. Adil membagi waktu itu penting agar pendidikan anak tidak terbengkalai.

7. Gunakan Alat Bantu Untuk Mendidik Akhlak Remaja, Di zaman modern ini, banyak sekali alat bantu yang bisa dimanfaatkan untuk menanamkan nilai-nilai akhlak pada diri anak. Selain itu, untuk membantu anak dalam mengembangkan kemampuan intelektual dan moralnya sebaiknya di rumah juga disediakan perpustakaan meskipun dalam kondisi terbatas untuk menarik minat anak membaca buku-buku bermutu.

8. Jadilah Orangtua Teladan, Secara psikologis remaja sangat membutuhkan panutan atau contoh dalam keluarga, sehingga dengan contoh tersebut remaja dapat mengaplikasikan dalam kehidupan sehari-hari. Sebaliknya jika remaja tidak memperoleh model atau perilaku yang mencerminkan akhlak karimah, tentu merekapun akan melakukan hal-hal yang kurang baik. Oleh karena itu, ayah harus berperan aktif mendidik anak-anaknya. Ayah harus menjadi teladan bagi anak-anaknya terutama dalam kepemimpinan karena seorang ayah adalah figur pemimpin keluarga. Jika seorang ayah ingin anaknya sholat, maka ayah harus sholat duluan. Jangan sampai menyuruh anak sholat tetapi sang ayah tidak melakukannya. Berikan keteladanan kepada anak jangan hanya pandai memerintah.

9. Orangtua Harus Kompak, Mendidik anak akan berjalan efektif jika orangtua berjalan dengan kompak, di mana orangtua harus memiliki visi dan misi yang sama. Hal ini penting diperhatikan orangtua, sebab ketidak kompakkan orangtua akan membuat anak mencari cela melakukan pelanggaran.

10. Kenali Teman-Teman Dekat Mereka, Islam menganjurkan umatnya agar selektif dalam memilih teman. Sebab apabila salah memilih teman dan bergaul dengan teman yang salah akan menjadi dampak yang buruk terhadap kepribadian seorang remaja. Agar hal itu tidak terjadi, orangtua berkewajiban mengetahui atau mengenali dengan siapa anak-anaknya 
bergaul, bahkan bila perlu orangtua harus mencarikan teman terbaik bagi anak-anaknya. Semua itu perlu dilakukan agar pembinaan akhlak remaja berjalan optimal sesuai dengan harapan setiap para orangtua. ${ }^{34}$

\section{KESIMPULAN}

Di era sekarang ini bukan hal yang mudah bisa mengasuh dan mendidik akhlak remaja, apalagi jika orangtua dikeluarga atau guru di sekolah tidak memiliki bekal yang cukup dalam penguasaan ilmu agama atau keterampilan mendidik anak. Tidak heran, banyak remaja yang sulit diatur dan membuat orangtua atau guru pusing dalam mencari pola asuh serta cara mendidik yang sewajarnya diterapkan kepada anak usia remaja.

Ketidakmampuan orangtua atau guru memahami aspek psikologis remaja akan berakibat fatal dalam berupaya pembentukan akhlak anak remaja. Demikian pula kesalahan orangtua atau guru dalam memilih strategi, metode dan kiat pembelajaran akan berakibat buruk terhadap perkembangan karakter remaja. Agar hal tersebut tidak terjadi Islam telah menberikan gambaran bagaimana kiatkiat dan metode dalam mendidik anak, maka secara tidak langsung memerintahkan kepada manusia terutama pada orangtua dalam memberikan pendidikan akhlak kepada anak-anaknya. Oleh sebab itu, Orangtua memegang peranan yang sangat penting dalam pendidikan dan bimbingan terhadap anak, karena hal itu sangat menentukan perkembangan anak untuk mencapai keberhasilannya. Tetapi hal itu juga sangat tergantung dari orangtua dalam menerapkan pendidikan khususnya dalam pembentukkan akhlak kepada anak remaja, karena orangtua pembuka mata rantai pendidikan yang pertama bagi anak dalam rumah tangga. Oleh sebab itu, orangtua berkewajiban memberi pendidikan dan pengajaran terutama pendidikan agama kepada anak-anaknya, guna membentuk sikap dan akhlak mulia, membina kesopanan dan kepribadian yang tinggi pada anak. Sebab jika para orangtua mengabaikan akan tanggung jawab terhadap pendidikan anaknya, maka kerusakan serta penyimpangan yang akan anak lakukan. Namun sebaliknya, selama orangtua mengikuti petunjuk yang Islam

\footnotetext{
${ }^{34}$ Amirulloh Syarbini dan Akhmad Khusaeri, Kiat-Kiat Islami Mendidik Akhlak Remaja, (Jakarta, Gramedia, 2012), h. 107
} 
ajarkan di dalam mendidik anak, maka anak akan terarah ke jalan yang baik pula di masa akan datang untuk menggapai kebahagian di dunia maupun kebahagian di akhirat.

\section{DAFTAR PUSTAKA}

Amirulloh Syarbini dan Akhmad Khusaeri, Kiat-Kiat Islami Mendidik Akhlak Remaja, (Jakarta, Gramedia, 2012)

Abdullah Nâshih Ulwan, Tabîyah Al-Aulad Fi al-Islam (Pendidikan Anak Dalam Islam) Terj. Jamaluddin Miri, (Jakarta: Pustaka Amani, 2007), Jilid 1

Departemen Agama, Al-Qur'an dan Terjemahannya, (Jakarta: Pustka Al-Fatih, 2005)

Lexy J. Moleong, Metodologi Penelitian Kualitatif (Bandung:Remaja Rosdakarya, 2013), Cet. 31

Moeslichatoen R, Metode Pengajaran di Taman Kanak-Kanak, (Jakarta: Rineka Cipta, 2004)

Musa Turoichan, Kado Perkawinan, Kiat Menciptakan Surga Dalam Rumah Tangga, (Surabaya: Ampel Mulia Surabaya, 2009)

Moh. Nazir, Metode Penelitian, (Bogor Selatan: Ghalia Indonesia, 2005)

Mulyadhi Kartanegara, Mozaik Khazanah Islam, Bunga Rampai dari Chicago, (Jakarta: Paramadina, 2000)

Mohammad Daud Ali, Pendidikan Agama Islam, (Jakarta: Rajawali Pers, 2008)

Riduwan, Skala Pengukuran Variabel-Variabel Penelitian, (Bandung: Alfabeta, 2013), Cet. Ke-10

Riduan, Belajar Mudah Penelitian Untuk Guru, Karyawan Dan Peneliti Pemula, (Bandung: Alfabeta, 2015)

Ramayulis, Samsul Nizar, Filsafat Pendidikan Islam: Telaah Sistem dan pemikiran para tokohnya, (Jakarta: Kalam Mulia, 2009)

S. Nasotion, Metode Research Penelitian Ilmiah, (Jakarta: Bumi Aksara, 2002), Cet. 5 
Sayyid Quthb, Tafsir Fi Zhilalil Qur'an: Di Bawah Naungan Al-Qur'an, (Jakarta: Gema Insani Press, 2001)

Zakiah Daradjat, Pendidikan Islam Dalam Keluarga dan Sekolah, (Jakarta: Ruhama, 1995) 